\title{
INTERACTIVE AND EDUCATIVE LEARNING MEDIA IN ENGLISH LANGUAGE TEACHING AT SENIOR HIGH SCHOOLS
}

\author{
Sitti Hadijah \\ Universitas Islam Riau \\ sittihadijah@edu.uir.ac.id \\ Marhamah \\ Universitas Islam Riau \\ marhamah@edu.uir.ac.id \\ Shalawati \\ Universitas Islam Riau \\ Shalawati@edu.uir.ac.id
}

DOI: 10.35445/alishlah.v12.i2.202

Accepted: July $5^{\text {th }}, 2020$. Approved: October $6^{\text {th }}, 2020$

Published: December $30^{\text {th }}, 2020$

\begin{abstract}
This research aims to describe senior high school students' perspectives about the use of learning media in English language teaching context and to investigate the sorts of interactive and educative learning media in English language teaching. This research worked on descriptive research design, both qualitative and quantitative data were collected through a questionnaire. This study involved 171 senior high school students who voluntary filled in the questionnaire. The research findings reveal that the use of learning media to support learning process needs to be improved since the media used needs to be adjusted with the current trend of learning that is technology-based learning media. In addition, Powerpoint slides, video, film, online or traditional games were found as interactive and educative learning media from the students' perspectives. The students are excited when the teachers are presenting media in their learning process, even though it only simply presented through Powerpoint. In other words, learning media has an essential role to support effective learning atmosphere for the students.
\end{abstract}

Keywords: Learning Media, Students' Perspective, Interactive, Educative, English. 
Al-Ishlah: Jurnal Pendidikan - ISSN: 2087-949o (p); 2597-940X (e)

Vol. 12, No. 2 (2020)

\title{
MEDIA PEMBELAJARAN INTERAKTIF DAN EDUKATIF PADA PENGAJARAN BAHASA INGGRIS DISEKOLAH MENENGAH ATAS
}

\begin{abstract}
Abstrak
Penelitian ini bertujuan untuk menggambarkan perspektif siswa/i di Sekolah Mengengah Atas terkait dengan penggunaan media pada pembelajaran Bahasa, serta untuk mengetahui jenis media yang digunakan untuk mendukung terlaksananya pembelajaran yang edukatif dan interaktif. Penelitian ini merupakan penelitian deskriptif yang menggunakan pendekatan kualitatif dan kuantitatif dengan melibatkan 171 siswa/i SMA di Pekanbaru, yang secara suka rela mengisi lembar angket. Hasil penelitian menunjukkan bahwa penggunaan media pembelajaran pada pengajaran bahasa Inggris di SMA perlu untuk ditingkatkan lagi karena media yang digunakan guru harus disesuaikan dengan pola pembelajaran saat ini, yakni media berbasis teknologi. Selain itu juga ditemukan beberapa jenis media pembelajaran yang dianggap interaktif dan edukatif menurut peserta didik, seperti owerpoint slides, video, film, permainanpermainan tradisional ataupun virtual. Para peserta didik sangat mengapresiasi penggunaan media pembelajaran yang ditampilkan oleh guru, meskipun hanya berupa media-media sederhana, seperti Powerpoint. Oleh karena itu dapat disimpulkan bahwa media pembelajaran memberikan peranan penting untuk mendukung terlaksannya pembelajaran yang efektif.
\end{abstract}

Kata Kunci : Media Pembelajaran, Tanggapan Siswa, Interaktif, Edukatif, Bahasa Inggris.

\section{PENDAHULUAN}

Terkait dengan kemajuan teknologi saat ini, ada banyak perangkat teknologi pendidikan yang dapat digunakan oleh guru untuk mendukung proses belajar mengajar, (Liu, Toki, \& Pange, 2014). Alat tersebut dapat berfungsi sebagai media pembelajaran yang menyediakan informasi untuk memenuhi kebutuhan pembelajaran, (Gu \& Guo, 2017). Oleh karena itu, guru dituntut untuk terampil bekerja dengan perangkat teknologi.

Dalam konteks pengajaran bahasa Inggris, para guru harus dapat bekerja dengan media pembelajaran yang terintegrasi dengan teknologi untuk memfasilitasi siswa untuk menguasai konsep pengajaran dan pembelajaran bahasa Inggris, keterampilan berbahasa, dan kesadaran lintas budaya bahasa Inggris. (Ling \& Yunus, 2016) menyatakan bahwa keberadaan teknologi menghadirkan nilai tambah yang dapat mempengaruhi kualitas pendidikan bahasa. Menurut (Zhang \& Zhang, 2015), ketersediaan tinggi dan keterjangkauan alat bantu teknologi dapat lebih meningkatkan proses pembelajaran bahasa. Dalam hal ini, 
Al-Ishlah: Jurnal Pendidikan - ISSN: 2087-949o (p); 2597-940X (e)

Vol. 12, No. 2 (2020)

para guru dapat bekerja dengan software atau hardware atau keduanya untuk meningkatkan pembelajaran.

Ada beberapa penelitian yang menemukan bahwa efektivitas integrasi teknologi sebagai media pembelajaran dalam konteks pengajaran bahasa Inggris, seperti dalam penelitian yang dilakukan oleh Oommen (2012) yang menyelidiki efektivitas presentasi PowerPoint sebagai alat pedagogis yang kuat dalam pengajaran bahasa Inggris. Kemudian, (Yogi, 2013) dalam studinya juga menemukan video conference sebagai salah satu faktor mendasar dalam meningkatkan keterampilan komunikasi bahasa, teknik presentasi pengajaran, materi, dan kesadaran budaya karena media tersebut memfasilitasi siswa untuk memiliki pengalaman belajar interaktif. Lebih jauh, (Kodir Al-Baekani \& Ridwan, 2018) dalam penelitiannya menemukan bahwa ponsel ada sebagai media interaktif dalam subjek mendengarkan yang luas karena kemudahannya untuk digunakan dan diakses. Selain itu, penggunaan media sosial, seperti Facebook juga dapat meningkatkan keterlibatan dan hasil siswa dalam pembelajaran Bahasa Inggris, (E. Akbari, Naderi, Simons, \& Pilot, 2016). Bahkan, menggunakan subtitle film juga terbukti sebagai media yang efektif dalam belajar bahasa Inggris, terutama untuk meningkatkan keterampilan mendengarkan dan penguasaan kosa kata, (Birulés-Muntané \& Soto-Faraco, 2016).

Berdasarkan hasil penelitian-penelitian sebelumnya, dapat disimpulkan bahwa guru bahasa Inggris dapat bekerja dengan beberapa perangkat teknologi dalam proses belajar mengajar bahasa Inggris yang telah terbukti efektif untuk meningkatkan kegiatan pembelajaran. Namun, dalam beberapa kasus integrasi teknologi dalam konteks pengajaran bahasa Inggris tidak dapat hanya dilaksanakan oleh para guru karena beberapa hambatan yang biasanya muncul selama implantasi teknologi sebagai media pembelajaran, (Hawanti, 2014), (Hsu, 2016), (Z. Akbari, 2015), (Aslan \& Zhu, 2016). Secara umum, masalah dipengaruhi oleh kurangnya kompetensi guru, kurangnya ketersediaan teknologi, waktu guru yang tidak memadai untuk mempersiapkan dan bekerja dengan perangkat teknologi, dan juga kurangnya dukungan teknis.

Terkait dengan uraian diatas, penelitian ini diajukan untuk memperoleh informasi terkait dengan penggunaan media pada pembelajaran Bahasa Inggris di Sekolah Menengah Atas, serta untuk mengetahui jenis media yang digunakan untuk mendukung terlaksananya pembelajaran yang edukatif dan interaktif pada konteks pembelajaran Bahasa Inggris berdasarkan tanggapan para siswa/siswi, selain itu juga untuk mendapatkan informasi terkait dengan karakteristik media interaktif dan edukatif berdasarkan siswa.

Sehingga, melalui penelitian ini dapat diperoleh informasi tentang intensitas penggunaan media pembelajaran, jenis media yang digunakan, teknik guru dalam menggunakan media, serta makna media pembelajran bagi peserta didik, yang 
Al-Ishlah: Jurnal Pendidikan - ISSN: 2087-949o (p); 2597-940X (e)

Vol. 12, No. 2 (2020)

mana informasi tersebut sangat dibutuhkan untuk mendukung terlaksananya kegiatan pembelajaran yang efektif didalam kelas, serta mendukung pengimplementasian kurikulum K13 yang sangat terkait dengan penggunaan media selama kegiatan belajar dan mengajar berlangsung.

\section{METODE PENELITIAN}

Penelitian dilaksanakan di dua sekolah, yang mana kedua sekolah tersebut merupakan dua sekolah swasta yang berada di Kota Pekanbaru. Kedua sekolah tersebut merupakan sekolah yang terakreditasi nasional oleh Badan Akreditasi Nasional, Sekolah dengan kategori A. Penelitian ini dilaksanakan di kedua sekolah tersebut pada tahun akademik 2019/2020. Para siswa/i pada tingkat XI dan XII dari kedua sekolah tersebut diminta untuk mengisi kuesioner yang dilakukan secara online dengan menggunakan aplikasi google form. Berdasarkan tanggapan para siswa/i dari kedua sekolah, ada 171 siswa/i yang memberikan tanggapan mereka terkait dengan penggunaan media pembelajaran di dalam kelas.

Penelitian ini merupakan penelitian deskriptif yang melibatkan data kualitatif dan kuantitatif yang diperoleh dari lembar kuesioner. Adapun tahapan pada penelitian ini dijelaskan pada informasi berikut: (1) tahapan ini terdiri dari beberapa rangkaian kegiatan, dan salah satu nya terkait denga proses persipaan penelitian, seperti mempersiapkan lembar kuesioner dan daftar pertanyaan yang akan digunakan pada saat pengumpulan data. Selanjutnya, lembar kuesioner yang akan digunakan divalidasi oleh tim validator. Pada tahapan ini juga, tim peneliti menentukan sekolah yang akan dilibatkan selama proses pengumpulan data. (2) proses pengumpulan data dilakukan pada tahapan ini, yakni dari lembar kuesioner. Proses pengumpulan data dilakukan di sekolah-sekolah yang telah ditentukan untuk menjadi perwakilan dari siswa/i SMA dan guru SMA di Pekanbaru, pemilihan sekolah dilakukan dengan menggunakan purposive sampling technique, yakni dengan melibatkan sekelompok siswa/i dan guru bahasa Inggris yang berasal dari dua sekolah di Kota Pekanbaru yang memiliki karakteristik yang sama terkait dengan pengajaran bahasa Inggris.. (3) selanjutnya, data diolah untuk mendapatkan informasi yang dibutuhkan dan dianalisa secara kualitatif dan kuantitatif.

\section{HASIL DAN PEMBAHASAN}

\section{A. Penggunaan Media Pembelajaran pada Pengajaran Bahasa Inggris di Sekolah Menengah Atas}

Informasi berikut menjelaskan tentang jenis-jenis media pembelajaran yang mendukung proses belajar bahasa Inggris. Para siswa/i diminta untuk memberikan tanggapan mereka tentang jenis media pembelajaran yang pernah mereka gunakan pada proses belajar bahasa inggris, serta seberapa sering mediamedia tersebut digunakan. 
Al-Ishlah: Jurnal Pendidikan - ISSN: 2087-9490 (p); 2597-940X (e)

Vol. 12, No. 2 (2020)

Penggunaan poster pada proses pembelajar sangat jarang digunakan oleh guru, hal tersebut dapat diketahui dari hampir 50\% dari peserta didik mengemukakan bahwa poster tidak pernah digunakan didalam kelas, selanjutnya sekitar 30\% siswa jarang menggunakan poster selama kegiatan belajar berlangsung, sedangkan sekitar $20 \%$ siswa memiliki jawaban yang beragam, yakni sangat sering, sering, dan cukup sering.

Terkait dengan penggunaan buku cetak, para peserta didik memiliki tanggapan yang sangat berbeda dibandingkan dengan penggunaan poster sebagai media pembelajaran. Buku cetak sebagai media belajar berada pada kategori sangat sering dan sering digunakan selama proses kegiatan belajar mengajar berlangsung, sekitar $75 \%$ siswa mengemukakan hal tersebut, namun hanya $25 \%$ dari mereka yang mengemukakan bahwa buku cetak cukup sering, jarang, dan tidak pernah digunakan. Berdasarkan temuan ini, dapat dimaknai bahwa pada era teknologi saat ini, penggunaan buku cetak pada proses pengajaran bahasa Inggris masih memiliki peranan yang penting sebagai media belajar bagi para siswa karena media ini berfungsi sebagai media penyaji yang memberikan informasi kepada para siswa/i.

Selain mengidentifikasi frekuensi penggunaan poster dan buku cetak sebagai media belajar bahasa Inggris, penggunaan media cetak, seperti koran, majalah, dan gambar cetak juga jarang digunakan didalam kelas. Tidak ditemukan perbedaan yang signifikan terhadap frekuensi penggunaan koran atau majalah dan gambar cetak sebagai media belajar bahasa Inggris. Kedua kelompok media tersebut mendominasi pada kategori tidak pernah dan jarang, yang berkisar $60 \%$ $70 \%$ siswa/i yang mengemukakan pengalaman mereka terkait dengan penggunaan media tersebut. Sungguh sangat ironis sekali, media sederhana tersebut masih jarang digunakan di dalam kelas, bahkan tidak pernah digunakan.

Sesungguhnya pada konteks pengajaran bahasa Inggris pada tingkat sekolah menengah atas, ada beberapa materi pelajar yang memungkinkan untuk menggunakan koran, majalah, atau gambar cetak sebagai media pembelajaran, seprti ketika mengajarkan materi pelajaran tentang "report text", atau "announcement". Selain itu, penggunaan materi autentik, seperti koran dan majalah dapat meningkatkan motivasi belajar siswa/i, (Rao, 2020).

Terkait dengan penggunaan perangkat teknologi sebagai media belajar, seperti penggunaan Powerpoint Slides, audio/rekaman suara, audio dan gambar, film, dan video singkat, ditemukan beragam frekeunsi penggunaan pada mediamedia tersebut, meskipun sebahagian besar siswa/i mengemukakan bahwa mereka masih belum pernah menggunakan media-media tersebut untuk mendukung kegiatab belajar mereka selama di kelas. Keseluruhan perangkat teknologi tersebut, masih sangat minim diintegrasikan pada kegiatan belajar mengajar bahasa Inggris dikelas, kondisi terssebut biasanya terkait erat dengan sarana dan 
Al-Ishlah: Jurnal Pendidikan - ISSN: 2087-9490 (p); 2597-940X (e)

Vol. 12, No. 2 (2020)

prasarana yang mendukung kegiatan belajar dengan menggunakan teknologi, seperti contoh penggunaan slide powerpoint sebagai media untuk menyajikan informasi yang dapat memfasilitasi para siswa/i untuk mengobservasi, menganalisis, mengekplorasi, dan mengkomunikasikan topik yang sedang dipelajari menjadi sesuatu yang sangat mewah untuk ditampilkan di dalam kelas karena masih minimnya alat-alat untuk mendukung penggunakan media powerpoint tesebut.

Meskipun pemerintah telah berupaya untuk menfasilitasi sekolah-sekolah dengan perangkat teknologi, namun banyaknya jumlah sekolah yang membutuhkan dukungan infrastruktur teknologi menyebabkan belum meratanya dukungan dari pemerintah, sehingga tidak mengherankan ketika masih sangat jarang, bahkan tidak pernah digunakannya produk teknologi sebagai media untuk mendukung pembelajaran baik didalam maupun diluar kelas. Tidak dapat dipungkiri bahwa pengunaan teknologi bukanlah suatu strategi yang dapat diimplementaskan dengan mudah, melainkan membutuhkan kesabaran dan penyesuaian terkait dengan kurikulum, kondisi sekolah, kompetensi guru, fakto keuangan sekolah, (Ammade, Mahmud, Jabu, \& Tahmir, 2018). Berdasarkan data yang diperoleh, berkisar $60 \%-70 \%$ siswa/i yang jarang bahkan tidak pernah memiliki pengalaman belajar dengan menggunakan perangkat teknologi diatas sebagai media belajar mereka.

Disamping itu, masih sangat jarangnya penggunaan komputer dan laptop juga ditemukan pada penelitian ini. Lebih dari 50\% siswa/i yang memberikan tanggapan bahwa penggunaan komputer dan laptop sebagai media penyaji informasi di dalam kelas masih sangat jarang, bahkan sebahagian siswa/i tidak memiliki pengalaman belajar dalam menggunakan media tersebut. Pada umumnya, minimnya sarana dan prasarana komputer dan laptop mempengaruhi intensitas dari penggunaan media ini karena media tersebut dapat digunakan secara efektif jika setiap siswa dapat berkerja dengan satu buah laptop ataupun komputer. Selanjutnya, terkait dengan persiapan materi pelajaran yang harus dipresentasikan dengan menggunakan media tersebut juga menjadi tantangan bagi para guru karena mereka biasanya memerlukan waktu khusus utuk merancang materi yang akan dipresentasikan melalui media laptop atau komputer. Biasanya para guru disibukkan dengan beragam tugas akademik lainnya, sehingga materi pembelajaran yang harus dipersiapakn ketika hendak mengajar dengan menggunakan laptop atau komputer sering terlupakan, sehingga hal tersebut mempengaruhi kesiapan guru dalam menggunakan media laptop atau komputer, (Hadijah, 2017).

Meskipun penggunaan laptop atau komputer sebagai media pembelajaran masih jarang digunakan pada pengajaran Bahasa Inggris, namun internet tampil sebagai media yang sering digunakan pada proses pembelajaran, hal ini berjalan 
Al-Ishlah: Jurnal Pendidikan - ISSN: 2087-9490 (p); 2597-940X (e)

Vol. 12, No. 2 (2020)

lurus dengan penggunaan aplikasi-aplikasi pada media smartphone, seperti kamus online dan social media. Hal ini menunjukkan bahwa penggunaan internet dan smartphone tidak dapat dipisahkan pada proses belajar peserta didik.

Intensitas penggunaan internet pada proses pembelajaran bahasa Inggris, pada umumnya berada pada kategori cukup sering, sering, dan sangat sering. Hal tersebut, diikuti dengan cukup seringnya penggunaan smartphone sebagai media belajar dan juga penggunaan aplikasi-aplikasi sosial media, seperti Facebook, Twitter, dan Instagram. Hanya berkisar $16 \%$ dari keseluruhan siswa yang dilibatkan pada penelitian ini yang tidak pernah menggunakan smartphone pada saat pembelajaran bahasa Inggris. Kondisi ini menyebutkan bahwa trend penggunaan smartphone sebagai media pembelajaran lebih tinggi dibandingkan dengan menggunakan laptop ataupun komputer. Pada sebuah penelitian telah ditemukan bahwa penggunaan smartphone pada proses pengajaran bahasa Inggris dapat meningkatkan partisipasi peserta didik, namun hal tersebut memerlukan keterampilan guru untuk dapat menggunakannya sebagai media yang efektif, (Nicolas \& El-aly, 2018).

Terkait dengan maraknya penggunaan sosial media pada berbagai aspek kehidupan, tanpa terkecuali dibidang pendidikan, intensitas penggunaan media sosial sebagai media interaktif pada pembelajaran bahasa Inggris juga cukup tinggi yang ditunjukkan dengan beragamnya intensitas penggunaan sosial media, (Tantarangsee, 2017). Selanjutnya, penggunaan media objek yang mengandung informasi, seperti guru, siswa, dan benda-benda disekitar peserta didik memiliki intensitas penggunaan yang tinggi. Guru sangat sering menggunakan dirinya sendiri sebagai media pembelajaran, hal ini sepertinya menjadi pilihan yang sangat mudah untuk diaplikasikan selama proses pembelajaran, seperti contoh pada pengajaran keterampilan berbicara bahasa Inggris, guru sering memberikan contoh-contoh dalam mengungkapkan tuturan dalam bahasa Inggris atau menceritakan pengalaman pribadi mereka terkait dengan materi yang sedang disampaikan. Selanjutnya, siswa juga cukup sering dilibatkan sebagai media pembelajaran di dalam kelas, hal ini juga termasuk hal yang dapat dilakukan oleh guru dengan mudah karena banyak hal yang dapat dieksplorasi dari keberadaan siswa di dalam kelas. Selain itu, dengan melibatkan siswa sebagai media diharapkan dapat memotivasi siswa lainnya untuk berpartisipasi aktif pada proses pembelajaran. Selain melibatkan guru dan siswa sebagai media pembelajaran, guru juga sangat sering menggunakan benda-benda di sekeliling peserta sebagai media pembelajaran. Intensitas penggunaan benda-benda di sekeliling peserta didik, tidak memiliki perbedaan yang sangat signifikan dengan melibatkan guru sebagai media.

Akan tetapi, penggunaan penutur asli bahasa Inggris (native speaker), sebagai media objek yang mengandung informasi masih sangat jarang digunakan 
Al-Ishlah: Jurnal Pendidikan - ISSN: 2087-9490 (p); 2597-940X (e)

Vol. 12, No. 2 (2020)

oleh guru bahasa Inggris. Hampir $40 \%$ siswa/i tidak memiliki pengalaman belajar langsung dengan penutur asli bahasa Inggris, $28 \%$ jarang mendapatkan pengalaman tersebut, dan hanya $11 \%$ yang mengemukakan cukup sering belajar dengan punutur asli bahasa Inggris. Kondisi ini menunjukkan perlu adanya peningkatan penggunaan penutur asli Bahasa Inggris sebagai media belajar bagi peserta didik agar mereka terbiasa mempraktekkan bahasa Inggris dengan penutur asli bahasa Inggris.

Terkait dengan penggunaan teknologi yang menggunakan sosial platform, seperti Kahoot dan Google Classroom, ditemukan bahwa dua produk teknologi tersebut memiliki frekuensi penggunaan yang sangat rendah, sementara itu pada sebuah penelitian ditemukan bahwa Kahoot merupakan media yang efektif untuk meningkatkan penguasaan kosakata siswa/i pada proses pembelajaran, (Pede, 2017) . Namun, pada penelitian ini, para siswa sepertinya tidak mengenal aplikasiaplikasi tersebut dengan baik. Sebanyak 120 orang siswa dari 171 mengemukakan bahwa mereka tidak pernah menggunakan Kahoot sebagai media belajar bahasa Inggris, namun untuk penggunaan Google Classroom, hanya ada sekitar 40 dari 171 orang siswa yang tidak pernah menggunakan Google Classroom. Dalam hal ini, para guru hendaknya berpartisipasi aktif untuk menggunakan sosial platform tersebut karena Kahoot dan Google Classroom dapat diakses secara gratis di internet dan juga dapat memberikan pengalaman belajar bahasa inggris dengan lebih menyenangkan dan bermakna.

Selain penggunaan sosial platform, seperti Kahoot dan sosial media, para guru juga dapat menggunakan permainan sebagai media belajar yang interaktif. Pada dasarnya ada dua kelompok permainan yang dikenal oleh masyarkat pada umumnya, seperti permainan online atau yang dikenal dengan virtual game, dan juga permainan tradisional. Pada penelitian ini, tim peneliti juga menginvestigasi intensitas penggunaan permainan sebagai media belajar interaktif di Sekolah. Pada bagian ini, para peserta didik ditugaskan untuk memberikan tanggapan mereka terkait dengan intensitas penggunaan permainan online dan permainan tradisional pada proses belajar dan mengajar di dalam kelas.

Penggunaan online game sebagai media pembelajaran interaktif di kelas juga masih sangat jarang diimplementasikan oleh guru pada saat pembelajaran bahasa Inggris. Hampir 100 siswa mengemukakan tidak pernah memiliki pengalaman belajar bahasa Inggris dengan menggunakan online game, sekitar 30 orang mengemukakan cukup sering menggunakan media tersebut, namun terkait dengan penggunaan permainan tradisional, jenis permainan ini memiliki intensitas penggunaan yang lebih tinggi ketika dibandingkan dengan penggunaan online game. Terlihat bahwa para guru bahasa Inggris didalam kelas sudah pernah menggunakan jenis permainan tertentu untuk mengajak perserta didik 
Al-Ishlah: Jurnal Pendidikan - ISSN: 2087-949o (p); 2597-940X (e)

Vol. 12, No. 2 (2020)

berpartisipasi aktif selama proses belajar dan mengajar bahasa Inggris sedang berlangsung.

\section{B. Media Edukatif dan Interaktif berdasarkan Perspektif Siswa/i}

Peserta didik mengetahui dengan baik jenis-jenis media menarik yang dapat digunakan oleh guru dalam mendukung pelaksanaan pembelajaran bahasa Inggris, baik di dalam kelas maupun diluar kelas. Para peserta didik mengemukakan bahwa penggunaan media-media tersebut memberikan beragam manfaat bagi mereka pada saat proses pembelajaran berlangsung, seperti kemudahan dalam mendapatkan informasi, menciptakan atmosfer pembelajaran yang lebih menarik. Hal tersebut dapat ditemukan dari beberapa pernyataan peserta didik yang ditampilkan pada informasi berikut:

"Media pembelajaran yang paling menarik adalah guru tersebut bagaimana dia menjelaskan dan membantu kami para siswa biar tahu bahasa inggris secara lisan maupun tulisan."

"Saat guru menjelaskan dengan mencontohkan barang yang ada di sekililing kita,dan barang yang biasa di jumpai karena pembelajaran seperti itu membuat saya lebih cepat memahaminya."

Berdasarkan pernyataan diatas, dapat diketahui bahwa peserta didik mengetahui bahwa guru didalam kelas, tidak hanya berperan sebagai fasilitator selama kegiatan belajar berlangsung, tetapi guru juga dapat berperan sebagai media pembelajaran yang dapat memberikan contoh-contoh yang lebih nyata kepada peserta didik, baik secara lisan ataupun tertulis. Selain itu, peserta didik juga mengemukan bahwa powerpoint juga berperan penting untuk meningkatkan pemahaman mereka terhadap materi yang disampaikan.

"PowerPoint karena memberikan kemudahan dalam memahami informasi."

"Media yang baik berupa Audio Visual yang bisa menampilkan gambar bergerak serta suara. Contohnya Power Point. Jika menggunakan itu mungkin minat siswa lebih besar karena mudah dipamai."

Powerpoint yang berfungsi untuk menampilkan multimedia juga diyakini oleh perserta didik sebagai media pembelajaran yang dapat menciptakan kegiatan belajar dan mengajar menjadi lebih menarik. Selanjutnya, penggunaan laptop, video, LCD proyektor merupakan komponen penting yang terintegrasi satu sama lain. Dalam hal ini, para peserta didik juga meyadari dengan baik bahwa penggunaan media-media tersebut dapat memberikan pengalaman positif dalam proses belajar bahasa inggris. Berikut pernyataan para peserta didik terkait dengan hal tersebut:

"Menurut saya lebih menarik dengan cara menampilkan sebuah video dalam berbentuk cerita bahasa inggris atau video singkat, agar dalam proses belajar dan belajar tidak sangat membosankan." 
Al-Ishlah: Jurnal Pendidikan - ISSN: 2087-949o (p); 2597-940X (e)

Vol. 12, No. 2 (2020)

"Menurut saya, ketika belajar bahasa inggris, saya lebih paham jika dengan adanya video singkat dalam bahasa inggris."

"Menggunakan laptop atau LCD proyektor, karena dengan menggunakan media tersebut guru dapat menerangkan materi disertakan dengan contoh yang dapat berupa gambar atau video dengan mudah."

"Menurut saya, yang paling menarik sih melalui video, lebih baik lagi kalo ada subtitle bahasa inggrisnya, jadi selagi mendengarkan belajar juga dari tulisannya, terus juga asik kan dari video, juga dari game game tanpa media elektronik juga seru, pokoknya semua jam belajar itu seru kalo misalnya ada waktu istirahatnya, otak kan ga bisa dipaksa buat terus terusan berpikir."

Para peserta didik juga mengemukakan bahwa kegiatan belajar dapat berlangsung menarik ketika guru membawa permainan-permainan menarik ke dalam kelas. Dalam hal ini, para perserta didik mengharapkan guru bahasa Inggris mereka untuk mempersiapkan permainan, baik permainan itu permainan elektronik atau permainan tradisional yang dapat menjadi media belajar bagi peserta didik. Kahoot merupakan salah satu contoh media elektronik yang berbasis permainan yang dapat digunakan oleh guru sebagai media pembelajaran, dan untuk permainan tradisional, guru dapat mempersiapkan kartu-kartu yang akan digunakan pada permainan kartu yang dapat menstimulus peserta didik untuk meningkatkan kemampuan berkomunikasi secara lisan. Informasi berikut menampilkan pernyataan siswa/i tentang penggunaan permainan sebagai media pembelajaran.

"Melakukan kegiatan seperti menerapkan game/permainan dalam pelajaran menggunakan bahasa inggris/game tradisional."

"Menurut saya memakai bahasa Inggris dengan cara yang efektif dalam belajar dan tidak membosankan, seperti membuat games atau apapun yg unik berkaitan dengan pembelajaran tersebut."

"Bernyanyi dengan lagu inggris sambil belajar karena itu sangat menarik dan membuat saya semangat dalam belajar."

"Handphone karna ada kamus online jadi tidak perlu bawa kamus lagi."

Berdasarkan uraian di atas, dapat disimpulkan bahwa ada berbagai jenis media pembelajaran menarik yang dapat digunakan oleh guru, terutama pada konteks pembelajaran bahasa Inggris karena setiap media tersebut memiliki peran yang sangat efektif untuk membantu peserta didik dalam menambahkan pengetahuan mereka, serta media-media tersebut dapat menfasilitasi peserta didik untuk belajar dengan cara yang lebih menyenangkan, tanpa harus selalu mendengarkan penjelasan guru. 
Al-Ishlah: Jurnal Pendidikan - ISSN: 2087-949o (p); 2597-940X (e)

Vol. 12, No. 2 (2020)

\section{SIMPULAN}

Penggunaan media pembelajaran pada pengajaran Bahasa Inggris di Sekolah Menengah Atas perlu untuk ditingkatkan karena media pembelajaran dapat menfasilitasi peserta didik untuk mendapatkan pengetahuan dan mengembangkan keterampilan mereka dalam mempelajari Bahasa Inggris. Selanjutnya, penggunaan media pembelajaran yang terintegrasi dengan teknologi perlu untuk diimplementasikan terkait dengan perkembangan teknologi saat ini. Selain itu, para guru, terutama pada konteks pengajaran bahasa Inggris harus memiliki keterampilan dalam mengenali media pembelajaran yang menarik dan edukatif bagi peserta didik karena pada saat ini peserta didik sudah mampu menentukan jenis media pembelajaran yang dapat bersifat interkatif dan edukatif bagi mereka, seperti penggunaan powerpoint slides, video, lagu, maupun permainan tradisional maupun vitual/online.

\section{REFERENCE}

Akbari, E., Naderi, A., Simons, R.-J., \& Pilot, A. (2016). Student engagement and foreign language learning through online social networks. Asian-Pacific Journal of Second and Foreign Language Education, 1(1), 1-22. https:// doi.org/10.1186/s40862-016-0006-7

Akbari, Z. (2015). Current Challenges in Teaching/Learning English for EFL Learners: The Case of Junior High School and High School. Procedia - Social and Behavioral Sciences, 199, 394-401. https://doi.org/10.1016/j.sbspro.2015.07.524

Ammade, S., Mahmud, M., Jabu, B., \& Tahmir, S. (2018). Integrating Technology in English Language Teaching: Global Experiences and Lessons for Indonesia. International Journal of English Linguistics, 8(6), 107. https://doi.org/10.5539/ijel.v8n6p107

Aslan, A., \& Zhu, C. (2016). Influencing Factors and Integration of ICT into Teaching Practices of Pre-service and Starting Teachers. International Journal of Research in Education and Science, 2(359-369), 235.

Birulés-Muntané, J., \& Soto-Faraco, S. (2016). Watching subtitled films can help learning foreign languages. PLoS ONE, 11(6), 1-11. https://doi.org/10.1371/journal.pone.0158409

Gu, P., \& Guo, J. (2017). Digital case-based learning system in school. PLoS ONE, 12(11), 1-16. https://doi.org/10.1371/journal.pone.0187641

Hawanti, S. (2014). Implementing Indonesia;s English language teaching policy in primary schools: The role of teachers; knowledge and beliefs. International Journal of Pedagogies and Learning, 9(2), 162-170. https://doi.org/10.1080/18334105.2014.11082029

Hadijah, S. (2017). Investigaring Teachers ' Barriers to ICT ( Information Communication Technology Integration in Teaching English at Senior High Schools in Pekanbaru. Proceeding of the Fifth International Seminar on English Language and Teaching (ISELT-5), 302-310.

Hsu, P. S. (2016). Examining Current Beliefs, Practices and Barriers About 
Al-Ishlah: Jurnal Pendidikan - ISSN: 2087-949o (p); 2597-940X (e)

Vol. 12, No. 2 (2020)

Technology Integration: A Case Study. TechTrends, 60(1), 30-40. https://doi.org/10.1007/s11528-015-0014-3

Kodir Al-Baekani, A., \& Ridwan, I. (2018). Integrated of Mobile Phone as Interactive Media in Extensive Listening. SHS Web of Conferences, 42, 00006. https://doi.org/10.1051/shsconf/20184200006

Ling, A. T., \& Yunus, M. M. (2016). Secondary ESL Teachers' Receptiveness towards ICT Integration. Asian EFL Journal, 7(March), 5-18. Retrieved from http://www.elejournals.com

Liu, X., Toki, E. I., \& Pange, J. (2014). The Use of ICT in Preschool Education in Greece and China: A Comparative Study. Procedia - Social and Behavioral Sciences, 112(Iceepsy 2013), 1167-1176. https://doi.org/10.1016/j.sbspro.2014.01.1281

Nicolas, M. O. D., \& El-aly, S. (2018). the Smartphone As a Tool To Enrich an English Language Classroom in an Efl Environment. International Journal of Arts \& Sciences, 11(01), 441-450.

Oommen, A. (2012). Teaching english as a global language in smart classrooms with powerpoint presentation. English Language Teaching, 5(12), 54-61. https://doi.org/10.5539/elt.v5n12p54

Pede, J. (2017). The effects of the online game Kahoot on science vocabulary acquisition Part of the Science and Mathematics Education Commons, and the Special Education and Teaching Commons. 5-11. Retrieved from http://rdw.rowan.edu/etdhttp://rdw.rowan.edu/etd/2405

Rao, P. S. (2020). The use of authentic materials as motivational tool in the ESL or EFL classrooms. ACADEMICIA: An International Multidisciplinary Research Journal, 10(2), 7. https:/ / doi.org/10.5958/2249-7137.2020.00010.5

Tantarangsee, C. (2017). The Use of Social Media in Teaching and Learning: A Case of SSRU's Faculty Members. International Journal of Innovation, Management and Technology, 8(6), 471-476. https://doi.org/10.18178/ijimt.2017.8.6.773

Yogi, M. (2013). Developing Language and Teaching Skills Through Videoconferencing and Collaborative Projects: a Case Study of English Teacher Training Programs in Japan. International Journal of Arts \& Sciences, 6(4), 347-362.

Zhang, Z., \& Zhang, Z. (2015). Using Commonly Available Ict for English Learning: Experiences and Recommendations. International Journal of Arts $\mathcal{E}$ Sciences, 08(02), 189-197. 